\title{
On Safeguarding Economic Perspectives of Regional Enterprises in THE Trinational NEISSE REgION
}

\author{
Albrecht Löhr ${ }^{1}$; Nataly Straßberger ${ }^{2}$ \\ Bautzen University of Cooperative Education, \\ Faculty of Financial Management, \\ Löbauer Straße 1, 02625 Bautzen, Germany \\ e-mail: ${ }^{1}$ loehr@ba-bautzen.de; ${ }^{2}$ nataly.strassberger@web.de
}

\begin{abstract}
This article focuses on the economic development of especially small and medium-sized enterprises in the border triangle of Germany, Czech Republic and Poland. The motive for this article was primarily driven by the politically decided structural changes in the East German coal regions. While preparing this article, the authors found that this groundbreaking transformation resembles the unexpectedly occurring crisis originated by the corona virus in terms of analyzing, structuring measures and management principles. Organizations like economic development institutions located in the municipalities, networks or business initiatives and technology centers like the Bautzen-based Bautzen Innovation Center should play an important part in overcoming both challenges in its role as supporters of the regional economy and - for the innovation centers - host for new businesses.
\end{abstract}

\section{Keywords}

Regional economic structure; Future challenges; Economic perspective; Crisis management; Corona crisis.

\section{Introduction}

This article is based on discussions regarding scientific works of Nataly Straßberger as part of the study degree program Enterprise Resource Management led by Albrecht Löhr.

The key question is how planned structural changes as well as the corona crisis influence the economic development of small and medium-sized enterprises. The article illuminates the specific situation of the enterprises based in the triangle regions of Dolnoslaskie in Poland, Liberecky kraj in Czech Republic and especially the Görlitz-Bautzen region in Germany.

The latter main focus is influenced by the business areas of the company that supports Nataly's cooperative degree program at Bautzen University of Cooperative Education. This is Bautzen Innovation Center, which is also responsible for a technology center based in Dresden-Rossendorf.

This article starts with an overview of the regional economic structure in the Görlitz-Bautzen region in Germany called Upper Lusatia and challenges which the companies within this area might have to face in the future. Additionally, the article includes statements on change and crises and how to handle them since the authors also consider the effects of the current corona crisis on regional companies and the question of what these companies could possibly learn from this crisis.

The worked-out assumptions and findings have to be critically evaluated and reshaped. From a simplified point of view, the foresight balance and volumes of economic supply and need have to be modeled, defined and discussed. 
Preliminary Remarks

\subsection{Research Subjects and Objectives}

This article focuses on small and medium-sized enterprises in the border triangle Germany, Czech Republic and Poland.

The main objective is to examine the impact of the corona crisis and the structural change on regional companies and to make assumptions about how they can cope with it. This article should especially deliver a contribution on how to act as a company in the given circumstances as well as respond to change in related market settings in general.

\subsection{Research Methods}

The statements of this article are based on systematic literary research. Various current literature including reference books, journals, publications and news, has been evaluated and appropriate conclusions have been drawn. Additionally, different points of view have been combined and theses have been made, which will need further discussion.

\section{Overview of the Regional Economic Structure and Future Challenges}

In order to obtain a better overview of the initial situation in Upper Lusatia and challenges even without the effects caused by the corona crisis, the following subchapters outline the economic structure in Upper Lusatia and some general trends and challenges which may affect the companies within this region.

\subsection{Economic Region of Upper Lusatia}

Upper Lusatia is a region shaped by small and medium-sized companies (SME), so there are hardly any large companies. There is no mono-structure, which means that there are companies operating in various industries as well as services. Moreover, the economic structure is characterized by a mixture of traditional and modern companies.

Almost two thirds of employed people in Upper Lusatia work in the service sector, see [1]. Key industries in the service sector comprise information technology including software development and distribution as well as the tourism and leisure industry.

Regarding manufacturing companies, the most important industry is plant and mechanical engineering. About two thirds of Saxon companies in this industry are based in the districts of Bautzen and Görlitz, see [2]. In addition, textile industry as well as plastics industry are two main industries in Upper Lusatia. Many of the companies of the plastics industry work as automotive suppliers.

However, the region is classified as structurally weak. The main reason for this is the demographic development in Upper Lusatia as described in subchapter 2.2. But also, the added value measured by the gross domestic product (GDP) per capita in the districts of Bautzen and Görlitz is about 35 percent below the German average and about 14 percent below the Saxon average, as the graph in Figure 1 shows. 


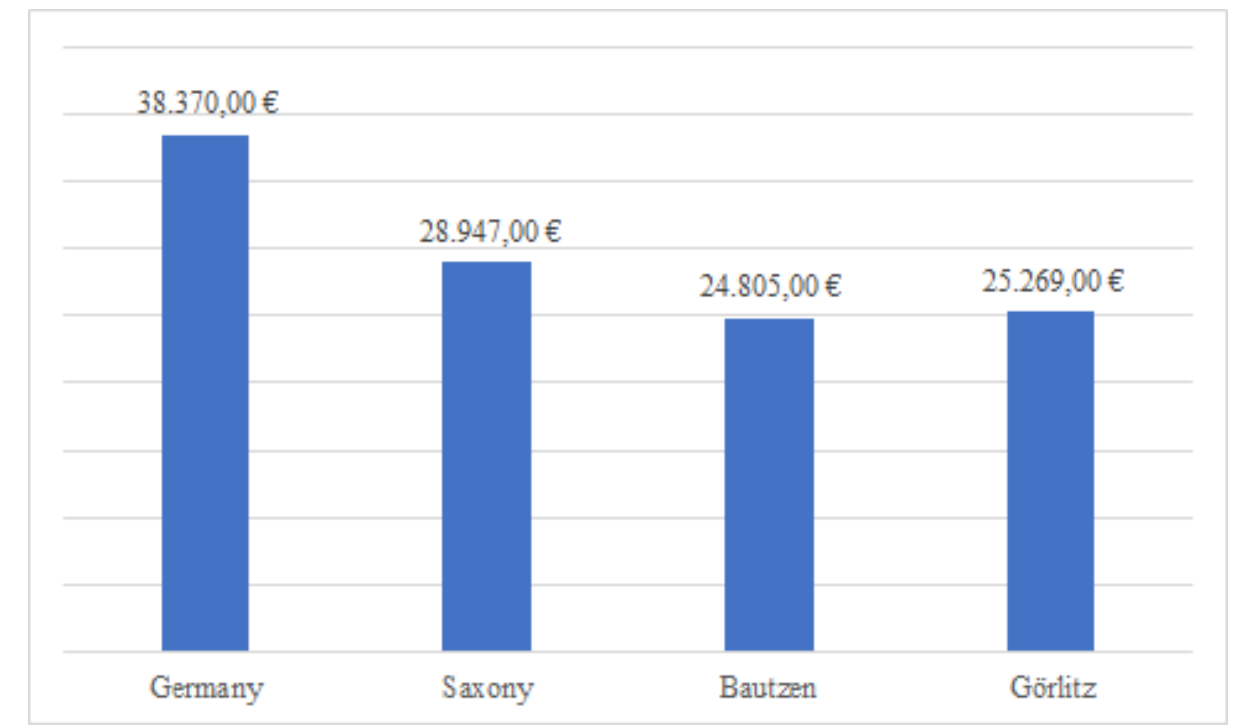

Source: [3] and [4]

Fig. 1: GDP per capita in 2016

Additionally, there is a big difference in the monthly gross salary considering the German median in comparison to the median of the districts of Bautzen and Görlitz, see [5]. That could be a reason why the region is not very attractive for labor migration.

In recent years the unemployment rate of Upper Lusatia has fallen to 5.7 percent in November 2019, see [6]. Nevertheless, it remains above the German average. Current figures already show effects in the unemployment rate of Upper Lusatia due to the corona crisis: In April 2020, the rate had gone up to 6.6 percent in the eastern part of Saxony, while unemployment in Germany had risen to 5.8 percent on average, see [7] and [8].

\subsection{Challenges due to Demographic Change}

According to forward projections of the Land Statistical Office of the Free State of Saxony, the population of Upper Lusatia will decrease by 7.1 percent in the district of Bautzen and by 10.6 percent in the district of Görlitz by 2030, see [9]. This decrease basically results from two effects - emigration and superannuation of the population.

At the moment it is already impossible to fill all vacancies with skilled workers. This applies especially to eastern and southern parts of Germany including the districts of Bautzen and Görlitz, see [10]. The emigration of young people and the superannuation exacerbate the shortage of skilled workers. That is also the reason why a number of companies think that the demographic change will probably be one of the biggest threats for them. However, due to the consequences of the corona-based crisis, which cannot be predicted in detail, this situation will alter in the future. Serious predictions are not available, which results in a significant uncertainty. However, these demographic circumstances will affect the economy in Upper Lusatia.

With a limited budget and small range, it is particularly hard for SMEs to find suitable young and skilled workers. As a consequence of the personnel shortage, expansion plans are inhibited or, even worse, the continuation of the company is at risk. To summarize, this could result in the economic strength to decline within the regions affected.

Measures have to be taken, so that either young people are encouraged to stay in Upper Lusatia or that they even immigrate to Upper Lusatia. Another solution could be substitutional measures, such as the rationalization of processes, for example through digitalization measures. However, all measures demand strict management decisions and cost money. 


\subsection{Challenges due to Structural Change}

In fact, there has already been a structural change in Upper Lusatia, which began in the 1990s with the reunification of Germany. With the loss of their role as one of the main energy producers in the German Democratic Republic (GDR), numerous power plants and surface mining businesses and their service entities as well as associated companies had to close down. Many of the employees in the lignite-processing sector were laid off. Consequently, the districts of Bautzen and Görlitz had to register a large migration to other areas during that time.

With the decision of the German government to back out of the lignite production by 2038, the remaining lignite companies are about to go out of business. This is going to affect about 12,500 jobs in the whole Lusatian area. However, Upper Lusatia will not be affected as severely as Lower Lusatia. In Upper Lusatia, lignite is structurally significant only in the district of Görlitz, see [11]. These changes in the lignite industry will also affect the neighboring Polish region (PGE Górnictwo i Energetyka Konwencjonalna S.A., Oddział KWB Turów) and indirectly the Czech region regarding the companies that own a significant part of Lusatian lignite mines (Energetický a Průmyslový Holding (EPH) and PPF Investments).

Nevertheless, it is important to prevent further emigration and to maintain economic output in Upper Lusatia, which means that investments to make the region fit for the future are necessary. There are recommendations to invest especially in digitalization, tourism as well as renewable energies and electromobility.

One way to strengthen the economic performance in Upper Lusatia could be the networking of the existing companies. In this way, innovations could be encouraged, and the companies could profit from synergy effects. At this point, there is also a big opportunity to expand cross-border cooperation with Poland and the Czech Republic, which could lead to improved competitiveness on all sides. To summarize, innovation is seen as a key to the successful survival of the structural change, see [11].

\subsection{Interim Summary}

To summarize, there are various challenges in order to prepare Upper Lusatia for a successful future. However, it is likely that the local companies will not manage these transformations 100 percent on their own. That is the reason for the provision of grants for regions including Upper Lusatia that are affected by the back out of the lignite production.

Additionally, it is one of the main tasks of regional economic development institutions to support local companies - for example with networking events, programs for encouraging innovation, support with management decisions through consulting activities, etc. All these institutions should cooperate to benefit from the strengths of each other and, as a result, to support the region in the best way possible. The key could also lie in improved cross-border cooperation.

\section{$3 \quad$ An Insight into Crisis and its Management}

The term "crisis" goes back to the Greek "Krisis" and describes the breach of continuities that provokes a situation demanding (management) decision. Thus, a crisis refers to a turning point under risk, meaning that given decision alternatives are controversial, often ambivalent see $[12$, p. 32]. Basically, a crisis is defined as an unexpectedly occurring incident with not foreseeable consequences. In other words, "a crisis ... is a risk manifested" (Heath, R. L. 
2009, cited in [13]) and leads to the instability of given systems, uncertainty and an urgent need of reacting.

Globalization and international cooperation mean growing complexity. Thus, it is no coincidence that we can see parallels to the VUCA concept that outlines the contextual situations, not only for businesses, but also in current societies, markets and eventually our planet. The acronym VUCA stands for Vulnerability, Uncertainty, Complexity and Ambiguity. This approach is useful for analyzing and understanding worldwide trends as well as regional changes, both occurring unexpectedly as well as in principle foreseeable as a result of given trends or decisions made.

Following this broader view, externally urged changes as principal disruptions of business models can be included in these considerations. Holding on (too long) to a traditionally successful business culminates in a crisis point that demands hard decisions. In the worst case, it may be too late though, so the only way out lies in liquidation. To apply these findings to our regional sight, both the current corona crisis as well as the process of foreseeable decarbonization of the considered region in the next decades can be used as examples.

Unlike hard changes, crises cannot be pre-managed generally. However, organizations ought to be prepared for accepting and diagnosing these abnormal situations and have to switch from daily business management to crisis management fast. These considerations are closely connected to aspects of organizational design, i.e. the mindset regarding planned structural changes are rather hindered or fostered. Management theory agrees widely in the picture of "coming before the situation", meaning simply come into acting instead of (only) re-acting. Once again, this acting happens under risk. Processing this active management can rarely bank on learned, established routines of daily problem solving. Crisis management systems and crisis squads as prepared structures can ease the named actions and lead to better results, see [13].

\subsection{Types and Sources of Crises}

Crises can basically be classified according to three criteria. The first one is the occurring and persisting of crises as follows:

- abruptly occurrent (as accidents, natural catastrophes)

- latently developing (business models, corona pandemic)

- permanent (climate change)

These types are not strictly distinctive, though representing typical patterns. Nevertheless, they are useful to reduce complexity and facilitate specific, appropriate management responses in complex or confusing situations. To systemize these types, factors like time, dynamic, disposability and communicative processes are available, see [13].

Secondly, crises are distinguished in being caused by internal or external influences. Organizational-environmental factors are, e.g., new competitors, disruptive technologies, market dislocations or shortage of resources triggering growing prices as well as stakeholder influences. Internal causes include management faults, differences amongst shareholders or commitment problems, see [14].

Finally, this article differentiates between strategic and operative challenges. The strategic view focuses on change or loss of strategic competitive advantages, whereas operative challenges refer to short-view problems such as quality faults or a decrease of turnover, see [15]. 
Hence, the current crisis caused by the COVID-19 virus, commonly called corona crisis, can be classified as latently developing, externally triggered and strategic. It is latently developing, because we must always be aware of the possibility of a comparable pandemic and it's not the first worldwide appearance of a virus of the SARS type. The external character is obvious in terms of a virus being a freak of nature, a mutation. The strategic challenge evolves from the range of the worldwide shock, the unforeseeable sufficient disposability of vaccine and drugs as well as the economic repercussions.

Overall, crises describe unplanned and unintended situations and processes that influence given forecasts and open ambivalent outcome varieties. They may endanger or even rule out the organization's survival. This is caused by threatening main goals, the risk of which is crucial to the existence of the considered subject, see [12, p. 34].

On the other hand, businesses crises can be considered as a natural part of a normal entrepreneurial lifecycle, so crises are simply a natural phenomenon for companies. The key question is less the existence of crises, but how they arise and how they are dealt with, see [16, p. 5].

Summing up, the following aspects describe the concept of crises:

- the threat to existence due to the threat of dominant objectives

- the ambivalence of the initial (metamorphosis or destruction)

- the process character as a time limitation of the crisis process

- the control problem in the sense of a limited influence on survival-critical processes

- the progressive loss of possibilities for actions in the crisis process

- $\quad$ surprises as well as time pressure and stress, see [12, p. 34] and [17, p. 14]

A broad variety of sources traditionally make a distinction between external and internal catalysts for crises. Against the background of globalization, a reshaping of key aspects is discussed. The main question is how and to what extent (international) macroeconomic influences are effectual and cannot be actively managed from the perspective of (internal) operative and strategic management. Strategic foresight and scenario techniques undoubtedly lead to a better understanding. However, the most frequently mentioned internal reasons of crises include faults as well as lapses regarding management and leadership. Secondly, nonexisting or dysfunctional controlling contributes to management failures, especially to a lack of ensuring decision-rationality.

\subsection{Managing Crises}

Usual routines are not applicable for a crisis being a new situation that demands at least a new combination of disposable managing tools or the establishing of completely new ones. This happens under time pressure and unpredictable operational or also reputational risks.

Nevertheless, any crisis provides a unique opportunity from the standpoint of change management: Thoughts, questions and decisions can be covered up relentlessly, which would not have been possible under normal circumstances. And not only covered up, but discussed, changed, re-managed forcefully in order to stabilize or even safeguard the mere existence of a given organization. Tools applied in case of such an incident foster quick de-automatization or liquidation of established reality-patterns and hence the creation and establishment of new procedures, see [15, p. 34].

Successful crisis management in the form of quickly activated (new) structures is only possible or at least more probable if it was part of the corporate strategy and culture before. Thus, functional crisis management grounds on a crisis plan with checklists, concrete measures in case of an emergency and the establishment of a crisis unit. The ideal crisis 
managers are generalists who can lead and are people-oriented, decision-making and determined and capable of analyzing situations quickly. It also means that everyday operating managers are not automatically suitable crisis managers, since the mind-set and main skills required are different, see [18].

Another key to overcoming crises is professional crisis communication - internally as well as externally. That is the reason why it has to be considered that this kind of communication differs significantly from the usual one. Hence, rules for crises communication should be part of crises plans. Especially in situations with fierce necessity to shift, all stakeholders are to be informed as a principle; in the best case main stakeholders are integrated.

Especially the understanding of and cooperation with staff members is crucial for overcoming crises. It has to be taken into consideration that change that does not respond to their basic acceptance and feelings is endangered. Firstly, people react to change with uncertainty and other deep-rooted emotions. Here, communication plays a crucial role, but must not be exhausted in information, but serve as a means of exchange and contact, see [19].

These objectives and solving tools could be subsumed as followed, see [20]:

- Crisis management provides restoration of the ability to act

- Operationally, crisis management is led and managed by a crisis squad

- The implementation is divided into problem analysis, situation assessment, decisionmaking, operational action, control and adaption

- Crisis communication is crucial

- Every company needs a crisis management team

- Crisis management must take care of affected stakeholders

- Informing staff comes first, also to avoid uncertainty or even opposition

- The crisis squad is to be trained in handling stress

- An organizational compliance culture helps to avoid crises

From a general point of view, tools and methods as strategic foresight and scenario techniques facilitate better understanding and clarification of appropriate managerial decisions.

Applied to the current situation, some proposals can be deduced from these points:

If we compare the actions taken in different countries, we could analyze the range of possible reaction on one hand as well as later acting vs. not reacting at all. Additionally, we saw typical details of managing under risk, because no one knew enough details to make classically derived decisions.

Crisis squads had already existed or were established. One of the hardest decisions to be made in most European countries were the harsh limitations of democratic, freedom and even constitutional rights. Then again as a crucial part of communication, many protective shields or direct financial support for businesses were allocated fast. The German government broke the constitutional rule of a balanced budget with Finance Minister Scholz even talking about a "financial bazooka". A huge part of the society accepted the limitations, which can be interpreted as a result of successful measures and understandable communication as well.

\section{The Corona Crisis and its Effects on Regional Companies}

The current corona crisis affects almost every industry. However, the effects differ considerably amongst companies. While some are even profiting from the crisis, a large number of companies are fighting for survival. In fact, every business model is being put to the test. 


\subsection{General Assumptions}

One phenomenon that can probably be observed in every company is how fast digitalization processes are advancing. Many companies have improved their internet presence. Additionally, there are companies that have developed new products and services or changed their production - either to help overcoming the crisis or simply to survive.

A huge and fast development that could be witnessed on a global level is the use of video conferencing systems by different providers. Some of them provided free access to the respective platform during the climax of the crisis - of course in expectance of future subscriptions subject to a charge. Additionally, changes in internal IT systems could be detected.

Some companies started the production of highly demanded goods such as face masks, which have quickly become a mass product - also in Europe. Supply chains were rapidly reorganized or derivative products were taken into account as well. In some cases, regional networks gained new importance.

However, companies are under a new kind of risk. In most economies the public is reported to be rather reluctant to spend money for reasons that include a current lack of income and a growing uncertainty regarding future prospects.

In the following, the tourism and leisure industry as well as automotive suppliers will be discussed in more detail as they are important components of the regional economy that is particularly affected.

\subsection{Tourism and Leisure Industry}

The tourism and leisure industry are probably hit hardest by the crisis - also in Upper Lusatia. On the basis of the general ruling of the Free State of Saxony and a number of federal orders, numerous hotels, restaurants and leisure attractions had to close for weeks, or they had to change their operational business.

According to calculations made by the Marketing-Gesellschaft Oberlausitz-Niederschlesien, there have been losses of more than 70 million euros in the tourism industry in Upper Lusatia so far - due to forced closures and a consequent absence of day-to-day business. About 16,000 employees in tourism and leisure industry are directly affected, the majority of them being on short-time work at the moment, see [21].

Despite the fact that the situation seems to be very dramatic these days, there is a chance for the industry to benefit from the crisis in the long term. Experts assume that holidays in Germany are going to become very attractive in 2020. This could be a big chance to make Upper Lusatia better known as a holiday area and to win a large number of new tourists, who may also return for future holidays.

That is the reason why regional hotels, restaurants and leisure attractions should take advantage of the current situation and expand their internet presence and marketing activities, because many holiday trips are being booked online during the corona crisis. In fact, they can reach new target groups throughout Germany this way.

From this point of view, the corona crisis may accelerate the expansion of the tourism and leisure industry in Germany and also Upper Lusatia in the long-term, which would be a positive contribution to the structural change, because existing potentials will be expanded further. 


\subsection{Automotive Suppliers}

Even without the effects of the corona crisis, the automotive industry faces a lot of challenges, e.g. due to electromobility. But since the outbreak of the coronavirus pandemic, the sales of cars have collapsed massively. In China as one of the biggest markets, sales have nosedived by up to 80 percent at times, see [22]. This leads to big overcapacities in the automotive industry, which affects the automotive suppliers directly in the form of decreasing sales. Hence, companies have secured only few orders and employees are working short time.

On the other hand, technology shifts towards electromobility at the expense of classical combustion engines result in a principal rebuilding of given added value architectures. Effects for component suppliers are e.g. a shortened need for metallic mechanical components. Moreover, higher standardization means growing mass orderings. This poses the question of the extent to which regional SMEs are prepared to meet this changing demand. In addition, the market strength of the big automobile companies may limit the flexibility in reacting for these companies - i.e. they either meet the expectations or they are out of this business. This merely drafted simulation implies several criteria of a crisis.

\section{$5 \quad$ Learnings from the Crisis}

Surely, we have to consider and emphasize the importance of crises management as a principle to be better prepared for different kinds of crises. The range spans from a family over every organization up to states and finally the whole world. Challenges are the associated tasks for SMEs against the background of their limited resources. Nevertheless, this finding also results in a kind of new allocation of resources. Many countries, including the EU, plan to store more protective equipment for instance. From a financial point of view, the huge supporting measures ties up billions of Euro in a mid-term perspective. These sums are not available for alternative investments. Measures of economic welfare in a state frame are affected as well as private spending power.

The demand for rethinking business models, the use of agile management tools as agility and flexibility to react to new circumstances may support the future success of every business. For many more traditionally minded organizations this (assumed) necessity implies demanding challenges as well as a given risk. Hence, willingness and skilled ability to reconsider own business models may be basically the crucial criteria for the success and existence of enterprises.

Rethinking global supply chains as one catalyst can push more local cooperation in addition to a global one. This newly balanced structure is often called the concept of glocalization understood as a dynamic consideration of both local and global aspects. We add the aspect of the special trinational chances in our region.

Also, the members of our ACC network could play a substantial role by engaging in scholarly debates with students and external partners as well as in consulting activities for businesses in our region. Experience from different cases should be structured and shared in a best-practice form. Finally, supporting a public debate on learning from overcoming the current situation can help establish the new mindset.

Thus, the authors invite the public to discuss it, because sticking together within the trinational region could help and advance all parties involved.

\section{Conclusion}

In conclusion, the current situation, caused by the spreading of coronavirus as well as the structural change caused by the back out of the lignite production by 2038 , can be referred to 
as crises. Both imply changes in enterprises concerning organizational structure, business models and therefore management decisions. Both crises are latently developing, caused by external influences and of strategic effect.

Due to the fact that the initial situation in the eastern part of Saxony is not optimal because of the decrease in population and the uncertainty regarding the future of several companies in Upper Lusatia, there are various challenges to be faced both at present and in future.

The authors believe that cooperation and networks at a regional as well as at cross-border level are essential both to overcome the corona crisis and to shape the structural change. Additionally, they assume that some of the regional SMEs will not be able to manage the associated changes completely on their own. That is the reason why the authors recommend the active involvement of the ACC network in consulting activities and exchange of experience in addition to other established economic development institutions.

Furthermore, the authors think that every crisis offers a chance to rethink and renew own products, services, supply chains or even the whole business model, which is also the key to innovation and therefore to success in the long term. It is important to not only react to current developments but also to take bold action and to make decisions as management always means making decision - in times of crises this is even more important.

\section{Literature}

[1] STATISTISCHES LANDESAMT DES FREISTAATES SACHSEN: Statistischer Bericht: Standardarbeitsvolumen der Erwerbstätigen im Freistaat Sachsen nach Kreisen 2000 bis 2017. [online]. 2020. [accessed 2020-05-11]. Available from WWW: https://www.statistik.sachsen.de/download/statistische-berichte/bericht_statistiksachsen_a-VI-11_standardarbeitsvolumen.pdf

[2] BAUTZNER ANZEIGER: Bautzen und die Oberlausitz als Wirtschaftsregion mit Potenzial. [online]. 2015. [accessed 2020-05-15]. Available from WWW: https://www.bautzen-anzeiger.de/bautzen/wirtschaft/12646_bautzen-und-dieoberlausitz-als-wirtschaftsregion-mit-potenzial-.html

[3] STATISTISCHES LANDESAMT DES FREISTAATES SACHSEN: Medieninformation 125/2018. [online]. 2018. [accessed 2020-05-16]. Available from WWW: $\quad$ https://www.statistik.sachsen.de/download/presse-2018/mi_statistiksachsen_125-2018_bip-landkreise-2016.pdf

[4] STATISTISCHE ÄMTER DER LÄNDER: Volkswirtschaftliche Gesamtrechnung der Länder: Gesamtwirtschaftliche Ergebnisse im Bundesländervergleich, Ausgabe 2019. [online]. 2019. [accessed 2020-05-16]. Available from WWW: http://vgrdl.de/VGRdL/tbls/VGR_FB.pdf

[5] BUNDESAGENTUR FÜR ARBEIT: Median der monatlichen Bruttoarbeitsentgelte von sozialversicherungspflichtig Vollzeitbeschäftigten der Kerngruppe nach Kreisen, kreisfreien Städte und ausgewählten Merkmalen sortiert nach der Spalte 1 (Insgesamt (Arbeitsort)). [online]. 2019. [accessed 2020-31-05]. Available from WWW: https://www.zdf.de/assets/median-der-monatlichen-bruttoarbeitsentgelte-nach-kreisenkreisfreien-staedten-und-ausgewaehlten-merkmalen-100 original

[6] BUNDESAGENTUR FÜR ARBEIT: Statistiken nach Regionen: Regionaldirektionsund Agenturbezirke. [online]. 2019. [accessed 2020-05-16]. Available from WWW: https://statistik.arbeitsagentur.de/DE/Navigation/Statistiken/Statistiken-nachRegionen/Statistiken-nach-Regionen-Nav.html 
[7] BUNDESAGENTUR FÜR ARBEIT: Die Entwicklung des Arbeits- und Ausbildungsmarktes im April 2020. [online]. 2020. [accessed 2020-05-27]. Available from WWW: https://statistik.arbeitsagentur.de/

[8] BUNDESAGENTUR FÜR ARBEIT: Willkommen bei Ihrer Agentur für Arbeit Bautzen. [online]. 2020. [accessed 2020-05-27]. Available from WWW: https://www.arbeitsagentur.de/vor-ort/bautzen/startseite

[9] STATISTISCHES LANDESAMT DES FREISTAATES SACHSEN: Regionalisierte Bevölkerungsvorausberechnung für den Freistaat Sachsen 2015 bis 2030. [online]. 2016. [accessed 2020-05-11]. Available from WWW: https://www.l-iz.de/wpcontent/uploads/2016/04/prog_ks_leipzig_stadt_14713000.pdf

[10] FEDERAL MINISTRY FOR ECONOMIC AFFAIRS AND ENERGY: Skilled professionals for Germany. [online]. 2020. [accessed 2020-05-11]. Available from WWW: https://www.bmwi.de/Redaktion/EN/Dossier/skilled-professionals.html

[11] DEUTSCHES INSTITUT FÜR WIRTSCHAFTSFORSCHUNG; WUPPERTAL INSTITUT FÜR KLIMA, UMWELT, ENERGIE gGmbH; ECOLOGIC INSTITUT gGmbH: Die Beendigung der energetischen Nutzung von Kohle in Deutschland: Ein Überblick über Zusammenhänge, Herausforderungen und Lösungsoptionen. [online]. 2018. [accessed 2020-05-24]. Available from WWW: https://www.ecologic.eu/sites/files/publication/2018/3537-kohlereader_final.pdf

[12] KRYSTEK, U.; LENTZ, M.: Unternehmenskrisen: Beschreibung, Ursachen, Verlauf und Wirkungen überlebenskritischer Prozesse in Unternehmen. In: A. Thießen (ed.), Handbuch Krisenmanagement. Springer Fachmedien Wiesbaden, 2013. DOI: $\underline{10.1007 / 978-3-531-19367-0}$

[13] MÖHRLE, H.: Topografie der Krise. In: OrganisationsEntwicklung. 1/2020. ISSN 0724-6110.

[14] BICKHOFF, N.; BLATZ, M. (eds.): Die Unternehmenskrise als Chance. Innovative Ansätze zur Sanierung und Restrukturierung. Heidelberg, Springer, 2004. DOI: $\underline{10.1007 / 978-3-642-17137-6}$

[15] MACK, O.; KÖPPL, L.: Auf der Talfahrt wenden. Den Wandel in Krisensituationen gestalten. In: OrganisationsEntwicklung. 1/2020. ISSN 0724-6110.

[16] THIEßEN, A.: (ed.): Handbuch Krisenmanagement. Springer Fachmedien Wiesbaden, 2013. DOI: $\underline{10.1007 / 978-3-531-19367-0}$

[17] SCHREYÖGG, G.: Unternehmensstrategie. Berlin, De Gruyter, 1984. ISBN-13 9783110098785.

[18] TRAUBOTH, J. H. (ed.): Krisenmanagement in Unternehmen und öffentlichen Einrichtungen. München, Richard Boorberg Verlag, 2016. ISBN-13 978-3415055179.

[19] DOPPLER, K.; VOIGT, B.: Feel the Change! Wie erfolgreiche Change Manager Emotionen steuern. Campus Verlag, 2012. ISBN-13 978-3593394732.

[20] SARTORY, B. et al.: Praxishandbuch Krisenmanagement, Zürich, Midas Management Verlag AG, 2016. ISBN-13 978-3907100424.

[21] BERGER, T.: Oberlausitz: Millionenverlust im Tourismus. [online]. 2020. [accessed 2020-05-16]. Available from WWW: https://www.saechsische.de/plus/oberlausitzmillionenverlust-im-tourismus-5202339.html 
[22] HAHNE, S.: Coronavirus und die Autoindustrie: Nagelprobe für eine Branche im Umbruch. [online]. 2020. [accessed 2020-05-24]. Available from WWW: https://www.deutschlandfunk.de/coronavirus-und-die-autoindustrie-nagelprobe-fuereine.2897.de.html?dram:article_id=473726 


\section{O OCHRANĚ EKONOMICKÝCH PERSPEKTIV REGIONÁLNÍCH PODNIKŮ V TROJZEMÍ REGIONU NISA}

Tento článek se zaměřje na ekonomický rozvoj zejména malých a středních podniků v hraničním trojúhelníku Německa, České republiky a Polska. Článek byl motivován především politickými strukturálními změnami ve východoněmeckých uhelných oblastech. Při př́íravě tohoto článku autoři zjistili, že tato průlomová transformace se podobá, pokud jde o analýzu, strukturování opatření a zásady ř́zení, neočekávané krizi způsobené koronavirem. Organizace, jako jsou instituce pro hospodářský rozvoj sídlící v obcích, sítě či obchodní iniciativy i technologická centra, jako je Inovační centrum se sídlem v Bautzenu, by měly hrát důležitou roli při překonávání obou výzev ve své roli podporovatelů regionální ekonomiky a $\mathrm{v}$ př́padě inovačních center - vytvářet podmínky pro nové podniky.

\section{SICHERUNG WIRTSCHAFTLICHER PERSPEKTIVEN DER REGIONALEN UNTERNEHMEN IN DER TRINATIONALEN NEIBE-REGION}

Der Artikel konzentriert sich auf die wirtschaftliche Entwicklung insbesondere der kleinen und mittelständischen Unternehmen im Dreiländereck Deutschland, Polen und Tschechien. Ausgangspunkt für diesen Artikel war vor allem der politisch beschlossene Strukturwandel unter anderem in den ostdeutschen Kohleregionen. Bei der Vorbereitung des Artikels stellten die Autoren fest, dass der damit verbundene tiefgreifende Wandel der unerwartet auftretenden Krise, die durch das Coronavirus ausgelöst wurde, ähnelt. Die Ähnlichkeit betrifft vor allem Analysen, Strukturierungsmaßnahmen und Managementprinzipien. Organisationen wie die Wirtschaftsförderungen der Kommunen, Netzwerke oder Wirtschaftsinitiativen und Technologiezentren wie das Technologie- und Gründerzentrum Bautzen sollten in ihrer Rolle als regionale Wirtschaftsförderer und als Anlaufstelle für neue Unternehmen eine wichtige Rolle bei der Bewältigung beider Herausforderungen spielen.

\section{O OCHRONIE PERSPEKTYW GOSPODARCZYCH PRZEDSIĘBIORSTW REGIONALNYCH DZIAŁAJĄCYCH NA STYKU TRZECH PAŃSTW W EUROREGIONIE NYSA}

Niniejszy artykuł poświęcony jest rozwojowi gospodarczemu w szczególności małych i średnich przedsiębiorstw działających na terenie przygranicznego trójkąta Polski, Czech i Niemiec. Napisanie artykułu zainspirowane było przede wszystkim politycznymi zmianami strukturalnymi na wschodnioniemieckich terenach górniczych. Przygotowując niniejsze opracowanie autorzy ustalili, że ta przełomowa transformacja, pod kątem analizy, organizacji działań i zasad zarządzania, podobna jest do nieoczekiwanego kryzysu spowodowanego koronawirusem. Organizacje takie, jak instytucje działające na rzecz rozwoju gospodarczego w gminach, sieci i inicjatywy gospodarcze oraz ośrodki technologiczne takie, jak Centrum Innowacji w Bautzen, powinny odgrywać ważną rolę w podejmowaniu obu wyzwań, pełniąc zadanie podmiotów wspierających gospodarki regionalne a - w przypadku ośrodków innowacji - stwarzających warunki dla powstania nowych przedsiębiorstw. 